\title{
Traits that Define the Different Alcohol Intensive Consume Type during the Practice of "Botellon"
}

\author{
Begoña Espejo ${ }^{1}$, María Teresa Cortés ${ }^{1}$, Beatriz Martín del Río ${ }^{2}$, \\ José Antonio Giménez ${ }^{1}$, and Consolación Gómez ${ }^{3}$ \\ ${ }^{1}$ Universitat de València (Spain) \\ ${ }^{2}$ Universitat Miguel Hernández (Spain) \\ ${ }^{3}$ Universidad Jaume I (Spain)
}

There is a phenomenon contributing to the current pattern of alcohol consumption among youngsters in Spain known as "botellon". From research financed by the National Plan on Drugs (2004-2007), data of 6009 youngsters (14-25 years old) were collected from three Spanish cities. Only individuals who engage in intensive consumption of alcohol $(n=2807)$ have been included. The purpose of this work has been to identify the different types of consumers at risk through a cluster analysis and to establish a profile for each particular group.

Four groups were differentiated by age, gender, alcohol consumption and years of consumption. It was observed that adolescent students and university students of the same sex consume similar quantities of alcohol, and justify their consumption alluding to personal factors, whereas university students refer to issues related to control of leisure. The consumption by males is the highest, and they are the most likely to seek drunkenness. They associate to a lesser degree their consumption with the possibility of developing an addictive process. In general, all youngsters consider that their consumption will have no negative consequences. These results indicate the need to come up with different alternatives, addressing the particularities of each group.

Keywords: botellon, intensive consumption of alcohol, cluster analysis, typology of consumers, youngsters.

Un fenómeno que en España favorece el actual patrón de consumo de alcohol juvenil es el conocido como botellón. A partir de una investigación financiada por el Plan Nacional sobre Drogas (2004-2007), se recogieron datos de 6009 jóvenes entre 14 y 25 años en tres ciudades españolas, considerando para este trabajo a quienes realizan episodios de consumo intensivo de alcohol $(n=2807)$. El objetivo ha sido identificar los distintos tipos de consumidores de riesgo intensivos mediante un análisis de conglomerados y establecer el perfil característico de cada uno.

Se diferencian cuatro grupos en función de la edad, sexo, cantidad de alcohol y años de consumo. Los estudiantes de secundaria ingieren cantidades de alcohol similares a las de los universitarios de su mismo sexo y aluden a aspectos personales para justificar este consumo, mientras que los universitarios hacen referencia a cuestiones asociadas al control del ocio. Los varones son quienes más consumen y más buscan la borrachera, aunque asocian en menor grado su ingesta con la posibilidad de desarrollar un proceso adictivo. En general, todos los jóvenes consideran que su consumo no tendrá consecuencias negativas. Estos resultados indican la necesidad de proponer alternativas diferentes atendiendo a las peculiaridades de cada grupo.

Palabras clave: botellón, consumo intensivo de alcohol, análisis de conglomerados, tipologías de consumidores, jóvenes.

The data presented in this work are part of a researched financed by the Plan Nacional sobre Drogas from the 2004-2007 notice.

Correspondence concerning this article should be addressed to Begoña Espejo Tort. Facultad de Psicología, Avda. Blasco Ibáñez, 21.46010-Valencia (Spain). E-mail: bespejo@uv.es 
Several research works have demonstrated that in the last decades there has been a homogenization of the entire Europe in terms of the alcohol consumption pattern by young people. It is increasingly more frequent the consumption of large quantities in periods of a few hours, especially over the weekend, losing control to some degree, and with periods of abstinence between the episodes (Anderson \& Baumberg, 2006; Cortés, Espejo, \& Giménez, 2007, 2008; Farke \& Anderson, 2007; Institute of Alcohol Studies, 2007; Kuntsche, Rehm, \& Gmel, 2004; Observatorio Español sobre Drogas, 2007).

Even though the existence of this consumption pattern has been acknowledged, a consensus among researchers is not appreciated, either in the definition or in the criteria that determine the consumption (Jackson, 2008; Lange \& Voas, 2001; Marczinski, Comb, \& Fillmore, 2007; Perkins, DeJong, \& Linkenbach, 2001; Wagner et al., 2007; Wechsler \& Nelson, 2001). Under terms such as "binge drinking", "heavy episodic drinking”, "high-risk drinking”, "risky drinking”, "excessive episodic consumption", "alcohol intensive consumption episodes", "concentrated consumption”, "binge consumption", they are referring to several aspects, such as the measure of the alcohol consumed in grams or in the number of consumptions, the frequency of the consumption, or the time interval in which the substance is ingested, to mention some.

In Spain this situation generated that in the $1^{\text {st }}$ Conference of Prevention and Promotion of Health in the Clinical Practice celebrated in Madrid in 2007, a group of experts in addictions recommended the use of the term "intensive alcohol consumption episode". This was defined out of criteria related to the quantity, duration and frequency, such as the ingestion of 60 or more grams of alcohol in males, and 40 or more grams in women, concentrated in a single session (alcoholemia not below 0.8g/1.) (Ministerio de Sanidad y Consumo, 2008). Both recommendations -terminological and of criteria- are included in this work.

One of the phenomena favouring the upsurge of this consumption pattern represents a juvenile risk in Spain and is called "botellon". In this, the youngsters meet up in groups, purchase alcoholic drinks and then they consume them, mainly in public places, such as squares and parks. In this phenomenon two interlinked dimensions are manifested, one is related to the health issue, derived from the excessive consumption of alcohol acknowledged by around $80 \%$ of the youngsters (Cortés et al., 2007, 2008; GiesyT, 2001; Navarrete, 2004), and another one associated to the social consequences that generates this activity in public areas -neighbours' complaints due to the noise, filthiness, etc (Díaz et al., 2009)-. Out of these two dimensions, the most visible one is the latter, despite the fact that each time the knowledge over the negative effects derived from the consumption of alcohol is greater, especially in the form of binge drinking among youngsters (Dhuse, 2005; Maurage, Pesenti, Philippot, Joassin, \& Campanella,
2009; Miller, Naimi, Brewer, \& Everett Jones, 2007; Tapert, 2007; White, 2007). An added factor to take into account is that the research carried out on the "botellon" (Alternativajoven, 2006a, 2006b; Baigorri, Fernández, \& GIESyT, 2004; Cortés et al., 2007, 2008; Elzo, Laespada, \& Pallarés, 2003; GIESyT, 2001; Gómez, Fernández, Romero, \& Luengo, 2008; Navarrete, 2004; Sánchez, 2001) have followed so heterogeneous procedures when collection information that it is very difficult to extract shared conclusions. Young people of different ages have been interviewed following different procedures (e.g., structured interviews, open questions, etc.) at a moment when the consumption within the "botellon" areas is taking place and, therefore, under the influence of alcohol, at different times, without considering incidents that can have an influence on the attendance to the "botellon" area (e.g., exams period, etc.). Besides, most of them limit themselves to describe formal aspects (date to carry it out, times of the day, transport to use...) and the pattern of consumption (type of drink, expenditure, frequency...). On a second plane, there is the analysis of the existence of different types of intensive consumption risk, as well as the assessment of the possible determinants of this behaviour -motives for practising it or the expected effects after the consumption- in spite of the fact that the works on the correlational nature confirm that these precise determinants are susceptible of modification with short educational interventions (GIESyT, 2001; Navarrete, 2004; Turrisi, 1999).

Today, in the limited results available, the following reasons stand out: leisure; social pressure and finances, as the grounds both, for the "botellon" practice, and for the alcohol consumption in this situation (Alternativajoven, 2006a, 2006b; Elzo et al., 2003; GIESyT, 2001). But this information is imprecise for it does not account for the existent variability among youngsters. A proof of that is found in the specifications over the results of the work of Navarrete (2004) with youngsters aged 14 to 17 years, in which the motives to attend the "botellon" also are differentiated clearly, as well as those to consume alcohol. In this work, the youngsters report that the motives to attend the "botellon" are group pressure, fun, the fact that it is something exclusive for youngsters, and the fact that they are not allowed in pubs and discos, giving less importance to not being able to talk easily or to the price of the alcoholic drinks. On the other hand, the main motive for the alcohol consumption during the "botellon" was the search of fun, followed, at a great distance, by other motives like the improvement of relationships with peers, doing things in a way different to others, because friends do it, and to get new/strong experiences.

But no research so far has analysed the possible differences depending on the level of consumption. Even when assessing the expected effects after the alcohol ingestion, this analysis is eluded, concluding that in general, the youngsters usually attribute alcohol with effects related 
to their motivations to attend the "botellon", stating that the consumption is what makes them feel enjoyment, like charlatans and sociable (Navarrete, 2004), pleasant feelings that are derived from a moderate consumption of alcohol.

However, despite the knowledge of the existence of several harmful consequences derived from an excessive consumption of alcohol among youngsters (Anderson \& Baumberg, 2006; O'Malley, Johnston, \& Bachman, 1998; Wechsler, Davenport, Dowdall, Moeykens, \& Castillo, 1994), they do not recognise the existence of any of them, which is an evidence of their low perception of risk.

In order to overcome the mentioned limitations, a research, financed by the National Plan on Drugs (20042007), was carried out, in which the participation in the phenomenon called "botellon" and the consumption of alcohol that takes place within it were analyzed, considering the different groups involved (youngsters aged ranging from 14 to 25 years, parents, media, security forces) assessing both, the background and the consequents of both behaviours. More concretely, this work, focused on the group of young people, attempts to establish the existence of differentiated groups of consumers of alcohol among youngsters that engage in the practice of "botellon", studying the definite traits in each group (Hair, Anderson, Tatham, \& Black, 1999; Picón, Varela, \& Real, 2003). With that aim, variables related to the motives for which the youngsters have this ingestion, the expected effects after the consumption of alcohol, the derived consequences of this type of consumption and the ingestion of other substances, were considered.

The same procedure to collect information was followed in three different cities, allowing the comparative of results in differentiated samples. In this way, besides progressing in the research into this area, more precise information will be obtained about some of the aspects to which it would be convenient to pay attention when the interventions to these groups are formulated.

\section{Method}

\section{Participants}

Data were collected from 6009 young people whose age ranged from 14 to 25 years in three cities of the Valencian Community (4083 in Valencia; 527 in Castellon; and 1399 in Alicante). Everybody participated voluntarily and they were informed about the confidentiality of their answers.

$73.6 \%(n=4222)$ participants manifested that they practice "botellon". In this work, only those people who had alcohol intensive consumption episodes during this practice, following the criteria of the Health and Consumption Ministry (2008) specified in our introduction, were included. Thus, the final sample was made of 2807 young people, out of whom $36.6 \%$ were men and $63.4 \%$ were women; $43.4 \%$ were university students (19 to 25 years old), and 56.6\% were high school and secondary school students (14 to18 years old).

\section{Procedure}

In the case of secondary school students, a stratified sample of students of Secondary School, High School and Formative Cycles was carried out. In the cities of Valencia and Alicante, a public centre was selected at random as well as another "concerted centre" of each district, for those cities were organised in educational districts. Each centre, jointly, included all levels of the considered studies. When there were not enough centres with these characteristics, the centres necessary to complete all levels were chosen at random. The survey was filled in by all groups of students of each level.

With respect to the university students, the qualifications of each area of knowledge were chosen (Basic Sciences, Social Sciences, Health Sciences, Education Sciences and Humanities) with greater number of registries, answering the questionnaire the largest group of each course.

\section{Instrument and variables}

After looking into the different results from research carried out on binge drinking and the "botellon" practice, a semi structured questionnaire ad hoc was designed aimed at youngsters to look into different aspects, such as age at the start, regularity, motives, expectatives, expected effects, leisure, shared activities with friends, perceived familiar alcohol consumption, etc. In this work we have only used the variables that help determine typologies of consumers, as well as those that help establish the traits of each group.

The typologies of consumers were established considering the following variables: (a) gender (male/female), (b) age group (university / secondary school students), and (c) grams of alcohol consumed during a "botellon" session, estimated by the number of reported consumptions and the degree of alcohol according to the type of spirits they reported to have consumed. Later on, we tried to find out if there were differences in the age at their earliest participation in the practice of "botellon" among the various groups.

On the other hand, the traits were analyzed in terms of the relative variables to the expectatives or the effects that are expected after the alcohol consumption, the motives to consume and to participate in the "botellon", the consequences of this ingestion and if other substances are also consumed. The expectatives were measured by asking "What effects do you think that alcohol produces in you?" and offering a continuation to the next list of possible effects: it helps lose inhibitions, it relaxes, it makes you lose the sense of time, it produces euphoria, it makes you sad, it makes you feel good, it makes you aggressive, it makes you take risks and makes you feel braver, it makes you more 
Table 1

Classification of the cluster analysis

\begin{tabular}{|c|c|c|c|c|c|c|}
\hline & \multirow[t]{2}{*}{ Clusters } & \multicolumn{2}{|c|}{ Sex } & \multicolumn{2}{|c|}{ Group } & \multirow[t]{2}{*}{ Grams } \\
\hline & & Male & Female & Univ. & $\begin{array}{l}\text { Second } \\
\text { School }\end{array}$ & \\
\hline & N (\%) & N (\%) & N (\%) & N (\%) & N (\%) & $\bar{X}(D T)$ \\
\hline $\mathrm{C} 1$ & $693(24.7)$ & $693(67.3)$ & 0 & 0 & $693(43.6)$ & $126.23(53.43)$ \\
\hline $\mathrm{C} 2$ & $898(32.0)$ & 0 & $898(50.4)$ & 0 & $898(56.4)$ & $87.80(41.33)$ \\
\hline $\mathrm{C} 3$ & $882(31.4)$ & 0 & $882(50.4)$ & $882(72.4)$ & 0 & $97.99(45.84)$ \\
\hline $\mathrm{C} 4$ & $336(12.0)$ & $336(32.7)$ & 0 & $336(27.6)$ & 0 & $130.73(51.05)$ \\
\hline
\end{tabular}

talkative, it makes you take risks in sex, and it makes you feel more confident. As for the motives to practice the "botellon" and consume in such a way, they were asked "Why do you practice the botellon"? and they were presented with two lists: (1) Motives to practice the "botellon": for fun, to get drunk, to disconnect from everything, and because my friends do it; (2) Motives to consume in such a way: because it is cheaper (financial reasons), to control the drink quality, because it is trendy, because of the crowdedness/noise of pubs, and to find a partner or friends with similar characteristics. Moreover, they were asked if they usually consumed cannabis or cocaine besides alcohol while they practice "botellon". All these variables were assessed using a dichotomous answer scale (yes/no).

Lastly, to measure the possible consequences derived from the consumption of alcohol during the "botellon", they were asked to what extent they considered the "botellon" as the cause of the following situations: bad relationships with their family and their partner; low academic performance; traffic accidents, fights and the possibility to "get hooked" on alcohol. These consequences were measured with an agreement scale ranging from " 0 " to " 10 ".

\section{Data Analysis}

Firstly, a two step cluster analysis was carried out to establish the different groups of youngsters that have intensive alcohol consumption within the "botellon" dynamic, determining the number of clusters using the Bayesian criteria of Schwarz. To carry out this analysis the data of the youngsters jointly from the three samples were used, as a previous work carried out a cluster analysis separating the data for each sample, getting the same classification (Cortés, Espejo, Martín del Río, \& Gómez, 2010). This result provided evidence on the validity of the answers, which allowed the three samples to be considered as a single group. Once the groups were established, the existence of differences statistically significant was verified through a variance analysis (ANOVA) over the grams of alcohol consumed during the participation in one session of the "botellon". Besides, we did an ANOVA in terms of the groups to find out if there were significant differences in the age of initiation at the "botellon" practice. In both cases, a posteriori tests of Games-Howell for non homogenous groups were done.

Following, a profile for each cluster was established in terms of the expected effects, the consumption motives, the consumption of other substances, and the consequences of alcohol consumption. To determine the differences among the resulting groups, we did a Chi-Square test with respect to each dichotomous variable (expected effects, motives and other consumptions), and ANOVA with respect to each variable of continuous response (consequences). In both cases the same a posteriori tests were carried out. All the analysis were carried out with the statistical package SPSS 15.0 for Windows.

\section{Results}

The cluster analysis provided the best solution retaining four groups (Table 1). All variables contributed significantly $(p<.001)$ to the formation of groups. The values of the contrast statistics for this level of significance were: sex $\left(\chi^{2} \geq 509.88\right)$, age group $\left(\chi^{2} \geq 438.90\right)$ and grams of alcohol consumed $(t \geq|4.94|)$.

Four groups are clearly differentiated: male secondary school students (c1), female secondary school students (c2), female university students (c3), and male university students (c4). With respect to the grams of alcohol consumed, the ANOVA show significant differences among all the groups $\left(F_{(3,2805)}=126,44, p<.0001, \mathrm{MCE}=2221.99\right)$. The a posteriori tests point out that males from both groups consume similar quantities of alcohol $(p=.561)$, whereas female university women consume significantly more alcohol than female secondary school students $(p<.0001)$. Besides, men consume significantly larger quantities of alcohol than women $(p<.0001)$, independently of the age group.

On the other hand, differences statistically significant are observed in the age of initiation in the "botellon" among the resulting four groups $\left(F_{(3,2753)}=189,42, p<.0001\right.$, MCE $=2.30$ ). University students, both, male and female, have started at the same age $(\mathrm{MU}=15.51$ and $\mathrm{FU}=15.39)$. The 
Table 2

Significant differences between the clusters in dependence of the expected effects, motives to consume, consumption of other substance and consequences

\begin{tabular}{|c|c|c|c|c|c|c|}
\hline & & \multirow[b]{2}{*}{$\chi^{2}$} & \multicolumn{4}{|c|}{ Clusters $^{1}$} \\
\hline & & & $\begin{array}{c}\mathrm{C} 1 \\
\mathrm{~N}(\%)\end{array}$ & $\begin{array}{c}\mathrm{C} 2 \\
\mathrm{~N}(\%)\end{array}$ & $\begin{array}{c}\mathrm{C} 3 \\
\mathrm{~N}(\%)\end{array}$ & $\begin{array}{c}\mathrm{C} 4 \\
\mathrm{~N}(\%)\end{array}$ \\
\hline \multicolumn{7}{|l|}{ EFFECTS } \\
\hline \multicolumn{2}{|l|}{ Makes you lose inhibition } & $121.21 * *$ & $253(36.8)$ & $401(44.9)$ & $542(61.5)$ & 205(61.4) \\
\hline \multicolumn{2}{|l|}{ Relaxes } & $21.27 * *$ & $90(13.4)$ & $65(7.4)$ & $68(7.8)$ & $39(11.9)$ \\
\hline \multicolumn{2}{|l|}{ Produces euphoria } & $19.02^{* *}$ & $286(42.4)$ & $324(36.7)$ & 294(33.8) & $147(44.8)$ \\
\hline \multicolumn{2}{|l|}{ Makes you sad } & $22.38^{* *}$ & $18(2.7)$ & $61(6.9)$ & $29(3.3)$ & 10(3) \\
\hline \multicolumn{2}{|l|}{ Makes you feel good } & $19.34 * *$ & $226(33.5)$ & 261(29.6) & 206(23.7) & $88(26.7)$ \\
\hline \multicolumn{2}{|l|}{ Makes you aggressive } & $23.02 * *$ & $45(6.7)$ & $29(3.3)$ & $20(2.3)$ & $20(6.1)$ \\
\hline \multicolumn{2}{|c|}{ Makes you take more risks; makes you braver } & $52.16^{* *}$ & $168(24.9)$ & $249(28.2)$ & 127(14.6) & $64(19.5)$ \\
\hline \multicolumn{2}{|l|}{ Makes you more talkative } & $32.64 * *$ & 324(48) & $526(59.6)$ & $520(59.8)$ & $163(49.5)$ \\
\hline \multicolumn{2}{|l|}{ Makes you take risks in sex } & $43.13 * *$ & 119(17.6) & $79(9)$ & $71(8.2)$ & $48(14.6)$ \\
\hline \multicolumn{2}{|l|}{ Makes you more confident } & $14.70^{*}$ & $182(27)$ & $223(25.3)$ & $168(19.3)$ & $81(24.6)$ \\
\hline \multicolumn{7}{|l|}{ MOTIVES ALCOHOL CONSUMPTION } \\
\hline \multicolumn{2}{|l|}{ Fun } & $49.56^{* *}$ & $560(81.5)$ & $729(81.7)$ & $609(69.1)$ & $258(77)$ \\
\hline \multicolumn{2}{|l|}{ Looking for drunkenness } & $52.95 * *$ & $349(50.7)$ & $337(37.7)$ & $311(35.3)$ & $166(49.7)$ \\
\hline \multicolumn{2}{|l|}{ To disconnect and switch off } & $77.61 * *$ & $242(35.2)$ & $344(38.6)$ & $180(20.5)$ & $92(27.5)$ \\
\hline \multicolumn{2}{|l|}{ Because friends do it } & $8.02 *$ & $334(48.2)$ & $375(41.8)$ & $375(42.5)$ & $154(45.8)$ \\
\hline \multicolumn{7}{|l|}{ MOTIVES TO PRACTICE BOTELLON } \\
\hline \multicolumn{2}{|l|}{ Finances } & $547.22 * *$ & $182(26.5)$ & $240(6.9)$ & $633(71.9)$ & $232(69.3)$ \\
\hline \multicolumn{2}{|l|}{ Control the drink quality } & $104.89 * *$ & $55(8)$ & $53(5.9)$ & $169(19.2)$ & $69(20.7)$ \\
\hline \multicolumn{2}{|l|}{ Crowdedness/noise pubs } & $65.53^{* *}$ & $91(13.2)$ & $108(12.1)$ & $213(24.2)$ & $82(24.5)$ \\
\hline \multicolumn{2}{|l|}{ It is trendy } & $20.61 * *$ & $28(4.1)$ & $38(4.3)$ & $8(0.9)$ & $11(3.3)$ \\
\hline \multicolumn{2}{|l|}{ To meet people/partner } & $38.64 * *$ & $160(23.2)$ & $185(20.7)$ & $107(12.2)$ & $59(17.6)$ \\
\hline \multicolumn{7}{|l|}{ OTHER CONSUMPTIONS } \\
\hline \multicolumn{2}{|l|}{ Cannabis } & $18.66^{* *}$ & 204(29.4) & $239(26.6)$ & $207(23.5)$ & $118(35.1)$ \\
\hline \multirow[t]{2}{*}{ Cocaine } & & $52.02 * *$ & $12(1.7)$ & $23(2.6)$ & $30(3.4)$ & $34(10.1)$ \\
\hline & $\mathrm{F}_{(3,2640)}$ & MCE & $\overline{\mathrm{X}}(\mathrm{DT})$ & $\overline{\mathrm{X}}(\mathrm{DT})$ & $\overline{\mathrm{X}}(\mathrm{DT})$ & $\overline{\mathrm{X}}(\mathrm{DT})$ \\
\hline \multicolumn{7}{|l|}{ CONSEQUENCES } \\
\hline Bad relationship with family & $36.06^{* *}$ & 7.88 & $3.23(2.95)$ & $4.16(2.86)$ & $3.06(2.73)$ & $2.56(2.57)$ \\
\hline Bad relationship with partner & $18.53^{* *}$ & 8.22 & $3.46(2.89)$ & $3.97(2.97)$ & $2.96(2.76)$ & $3.15(2.81)$ \\
\hline Low academic performance & $28.82^{* *}$ & 7.70 & $3.92(2.93)$ & $5(2.72)$ & $4.04(2.73)$ & $3.79(2.71)$ \\
\hline Traffic accidents & $18.53^{* *}$ & 5.77 & $7.45(2.66)$ & $8.12(2.16)$ & $7.83(2.34)$ & $7.10(2.61)$ \\
\hline Fights & $17.01^{* *}$ & 5.98 & $6.85(2.50)$ & $7.38(2.25)$ & $6.90(2.54)$ & $6.31(2.59)$ \\
\hline Possibility of getting "hooked" on alcohol & $16.40^{* *}$ & 7.58 & $5.43(2.92)$ & $6.26(2.60)$ & $5.81(2.74)$ & $5.24(2.84)$ \\
\hline
\end{tabular}

${ }^{*} p \leq .05 ;{ }^{* *} p \leq .0001 ;{ }^{1}$ Porcentage of "Yes" for each variable, within each cluster

same happens with adolescents, who start at the same time $(\mathrm{MA}=14.07$ and $\mathrm{FA}=14.02)$. However, all the adolescents have started participating in the "botellon" significantly earlier than the university students $(p<.0001$ in all cases).

In Table 2 the traits for each resulting cluster are shown.

In the first place, significant differences are observed among the four groups in all the analyzed variables, bar the one related to the effect of losing the sense of time. However, it is important to add that in some cases percentages or means are so low that those differences cannot be considered qualitatively relevant (e.g., only between $2.4 \%$ and $6.5 \%$ participants reported over the effect of feeling sad). In the case of the consequences, none of the groups are in agreement with the fact that alcohol consumption generates bad interpersonal relationships (with their family or their partner) or that it affects academic performance negatively.

Secondly, results show that, although there are significant differences between the four groups, there are 
certain determinants of their consumption behaviour that are common in all of them. The most frequent motive given is that related to the leisure (fun), followed by the positive effects derived from the consumption (loss of inhibition and feeling more talkative) and by the identification with the group (because friends do it).

More concretely, male university students (c4) associate the consumption of alcohol to that of cocaine or cannabis. Besides, according to the results of the a posteriori tests, they show a lesser degree of agreement than the other groups with the fact that consumption of alcohol can provoke fights $(p<.003)$, and consider to a lesser degree than women (c2 and c3) that this consumption is associated with traffic accidents $(p<.001)$ and that there is a probable link to an addictive process in the future $(p<.01)$.

Male secondary school students (c1), on the other hand, share with women of the same age (c2) an expected effect of wellbeing derived from the consumption and an increase in the level of confidence, taking certain risks. Moreover, both groups ( 1 and $\mathrm{c} 2$ ) drink to disconnect from problems and to find a partner, and to some extent because it is trendy. In terms of the consequences, from the a posteriori tests, male ( $\mathrm{c} 1$ and $\mathrm{c} 4$ ) reckon, to a lesser degree than women (c2 and c3), that the consumption of alcohol can cause traffic accidents $(p<.001)$ and consider a possible link to an addictive process $(p<.01)$.

Also, the male ( $\mathrm{c} 1$ and $\mathrm{c} 4$ ) are those who consume larger gram quantities of alcohol and search intently ethylic intoxication, stating, somewhat more than women do, that they drink because their friends do it. On the other hand, they consider that the consumption of these quantities of alcohol have the effect of dispelling tension, as well as generating a greater feeling of euphoria, aggressiveness and taking risks related to sex. As for female secondary school students (c2), they fall more into the depressing effect of alcohol and, according to the results from the a posteriori tests, it is observed that they have greater awareness than all the other groups in that alcohol can provoke fights $(p<.001)$ and that it can increase the probability of associating to an addictive process $(p<.006)$, although they coincide with female university students (c3) reporting to a greater extent that alcohol is associated to traffic accidents $(p<.01)$.

Lastly, female university women (c3) allude to motives related to controlling leisure (finances, control over the quality of spirits and social environment) that share with the male of the same age (c4).

\section{Discussion}

Congruent with previous works, the results show (Cortés et al., 2010) the existence of four differentiated groups of youngsters that engage in intensive episodes of alcohol consumption within the "botellon": male secondary school students (c1), female secondary school students (c2), female university students (c3) and male university students (c4), that consume different quantities of alcohol. In fact the analysis carried out over the grams of alcohol show that male, regardless of their age, consume the same quantities of this substance, a similarity that is not kept among the women. In this case, university students are the ones that have the largest consumptions. An additional aspect to take into account is that all the groups ingest the double quantity of alcohol grams from which intensive consumption is considered in each case.

The frequency with which this binging behaviour takes place stands out. Although in some other research works the frequency of the binging behaviour has been considered, in this work this variable is not included. This was measured and taken into account for the cluster analysis, but in the end it was not included as no relevant differences between the groups have been established. The frequency of the consumption was measured in terms of the number of days of the week, months of the year and years performing this behaviour. Neither of the first two variables was relevant when differentiating between the resulting groups, as all of them consume some 2-3 days a week and around 8 months a year, and the only variable that showed differences between the groups was the number of years of consumption. However, as it is plausible that university students have been consuming for longer, given they are older than the secondary school students, this variable was also excluded from the analysis.

Despite all this, it is important to stand out that when age at the initiation in the botellon practice is taken into account, it is proved that there is a significant decrease among the youngest ones. This shows that when adolescents reach the current age of the university students from this work, they will have performed this behaviour for longer. To this it is added the fact that they consume high quantities right from the start, with the proportional increase in the probability of the upsurge of bio-psycho-social consequences derived from itself.

When examining the traits of the resulting groups, even though all of them state that they consume alcohol to have fun, the secondary school students do it to a greater extent than the university students, considering it also a facilitator in social relationships. This focalization on the positive effects derived from the alcohol ingestion can be one of the reasons that may explain the high consumption of these youngsters, as their ingestion is similar to that of the university students of the same sex, although they are older and have been performing this behaviour for less time. This situation would support the need to reformulate the leisure model associated to the consumption of alcohol (Arbex, 2003; Baigorri, Chaves, Fernández, \& López, 2004; Baigorri, Fernández, \& GIESyT 2004; Sánchez, 2007), especially considering that this association is increasing among the younger population (Anderson \& Baumberg, 2006; Cortés et al., 2007; PNSD, 2009). 
On the other hand, men are the ones that consume the most and aim at drunkenness to a larger extent, even though they associate to a lesser extent the consumption with the possibility of developing an addictive process. This lack of knowledge or a high risk taking would imply a need to explain and clarify in this population the importance of considering the addiction as a process in which one can progress more or less quickly depending on the consumption pattern, and during which bio-psycho-social consequences more or less important come up throughout it.

The results found pose the necessity to review the consideration that youngsters consume alcohol in the street for financial reasons, for only the university students allude to reasons linked to the control of leisure (financial, control of the drink quality and crowdedness/noise at pubs) which offers additional information to the results of Navarrete (2004), allude also to motives focused on personal aspects (evasion and finding a partner, etc.)

On the other hand, it is also appreciated a different assessment of the negative psycho-social consequences towards a greater broadcasting in the media (fights, traffic accidents, etc.) (Baigorri et al., 2004; Plaza, Pardo, Cortés, Samper, \& Martínez, 2006), in contrast with the low level of importance given to the rest of consequences, despite the existing experimental evidence about it (Dhuse, 2005; Maurage et al., 2009; Miller et al., 2007; Tapert, 2007; White, 2007). Besides, in the concrete case of the interpersonal consequences it seems that it is necessary to work on the motivational expectatives derived from the consumption, for among the main motives for which they have this ingestion, there is, precisely, the search of socializing effects.

Thus, if the motives because of which alcohol is consumed during the botellon are considered jointly with the expected effects of that ingestion, there appear two differentiated groups in terms of age. On the one hand, the university students give motives of controlling leisure, as well as the leisure effect, of social relationships and of positive mood. Apart from that, the secondary school students make reference to the personal motives to consume alcohol, as well as the leisure effects, of social relationships and they focus on the ability to do things that otherwise they would not do (being able to take risks in sex, feeling braver, having more confidence). That is, the motives and expectatives of these youngsters interviewed are focused more on the internal aspects, whereas the university students focus more on the external ones.

These results point out that it would be adequate to propose alternatives directed more to the control of leisure in the case of university students, whereas for the secondary students it would be interesting to focus, also, on aspects related to personal improvement (self-esteem, interpersonal relationships management...) and the training in new leisure habits.

It is important to acknowledge that there is a limitation in our results, as only students were interviewed because of the difficulty involved in having access to and assessing, with the same rigor, the population at these ages, who are not students and perform the same behaviours.

With this work, a first approach to the different youngsters' groups that carry out intensive alcohol consumption episodes is made. In spite of the fact that similar data were found in three independent samples (Alicante, Castellon and Valencia) our results cannot be generalized to the whole Spanish population. For this reason, it would be interesting to assess if similar results are found in other cities. This would allow for adjustments in any intervention to optimize effectiveness, taking into account the peculiarities for each of the groups that have a risky intensive consumption of alcohol within the "botellon".

\section{References}

Alternativajoven (2006a). Bebiendo junto al Guadiana: Estudio sobre el botellón en el paseo fluvial de Badajoz [Drinking near the Guadiana: Study on the botellon in the side of the river in Badajoz]. Retrieved from http://www.alternativa joven.es/aljovex/docs/estudio-botellon.pdf

Alternativajoven (2006b). Bebiendo junto al Guadiana: Estudio sobre el botellón en el recinto ferial de Mérida [Drinking near the Guadiana: Study on the botellon at the fairgrounds in Mérida]. Retrieved from http://www.alternativajoven.es/ aljovex/docs/estudio-botellon-merida.pdf]

Anderson, P., \& Baumberg, B. (2006). Alcohol in Europe. London, England: Institute of Alcohol Studies. Retrieved from http://ec.europa.eu/health/archive/ph_determinants/life_style/alc ohol/documents/alcohol_europe_en.pdf

Arbex, C. (2003). Buenas prácticas y retos de los programas de ocio saludable [Good practices and challenges of healthy leisure programs]. Madrid, España: Asociación de técnicos para el desarrollo de programas sociales. Retrieved from http://www.pnsd.msc.es/Categoria2/publica/pdf/catalogo_ociosal udable.pdf

Baigorri, A., Chaves, M., Fernández, R., \& López, J. A. (2004). El botellón: localizando un conflicto postmoderno [Botellon: locating a postmodern conflict]. In A. Álvarez Sousa (Coord.), Turismo, Ocio y Deporte. VIII Congreso español de sociología [Tourism, Leisure and Sport. VIII Spanish Congress of Sociology] (pp. 111-130). A Coruña, Spain: Universidade da Coruña.

Baigorri, A., Fernández, R., \& GIESyT (2004). Botellón. Un conflicto postmoderno [Botellon. A postmodern conflict]. Barcelona, Spain: Icaria.

Cortés, M. T., Espejo, B., \& Giménez, J. A. (2007). Características que definen el fenómeno del botellón en universitarios y adolescentes [Characteristics that define the "botellon" in university students and adolescents]. Adicciones, 19, 357-372.

Cortés, M. T., Espejo, B., \& Giménez, J. A. (2008). Aspectos cognitivos relacionados con la práctica del botellón [Cognitive aspects of binge drinking]. Psicothema, 20, 396-402. 
Cortés, M. T., Espejo, B., Martín del Río, B., \& Gómez, C. (2010). Tipologías de consumidores de alcohol dentro de la práctica del botellón en tres ciudades españolas [Different typologies of alcohol consumers in the practice of "botellon" in three Spanish cities]. Psicothema, 22, 363-368.

Delegación del Gobierno para el Plan Nacional sobre Drogas (2009). Informe de la Encuesta Estatal sobre uso de drogas en Estudiantes de Enseñanzas Secundarias (ESTUDES) 2008 [Report of the Survey on drug use in Secondary School Students 2008]. Madrid, Spain: Ministerio de Sanidad y Política Social.

Díaz, M. J., Martín, R., Piñeiro, C., Palavecinos, M., Benayas, J., \& Alonso, L. E. (2009). Los impactos socio-ambientales del fenómeno "botellón": el caso de la ciudad de Madrid [Socioenvironmental impacts of the phenomenon "botellon" for the city of Madrid]. Medio Ambiente y Comportamiento Humano, 10, 117-135.

Dhuse, S. R. (2005). Consequences of binge drinking: Risk and protective factors. Dissertation Abstracts International-B, 67, 537.

Elzo, J., Laespada, M. T., \& Pallarés, J. (2003). Más allá del botellón. Análisis socioantropológico del consumo de alcohol en los adolescentes y jóvenes de la Comunidad de Madrid [Beyond the "botellon". Socio-anthropological analysis of alcohol consumption in adolescents and youth of the Community of Madrid]. Madrid, Spain: Agencia Antidroga, Ministerio de Sanidad. Retrieved from https://www.obrasocial cajamadrid.es/Ficheros/CMA/ficheros/OSSoli_JovenesValores0 6.PDF

Farke, W., \& Anderson, P. (2007). El consumo concentrado de alcohol en Europa [Binge drinking in Europe]. Adicciones, 19, 333-340.

GIESyT (2001). El botellón en las ciudades de Badajoz, Cáceres, Mérida y Plasencia [The "botellon" in the cities of Badajoz, Cáceres, Mérida and Plasencia]. Mérida, Spain: Universidad de Extremadura, Ministerio de Cultura. Retrieved from http://www1.unex.es/eweb/sociolog/botellon\%201.pdf

Gómez, J. A., Fernández, N., Romero, E., \& Luengo, A. (2008). El botellón y el consumo de alcohol y otras drogas en la juventud ["Botellon" and alcohol and other drug use in youth]. Psicothema, 20, 211-217.

Hair, J. F., Anderson, R. E., Tatham, R. L. \& Black, W. C. (1999). Análisis multivariante ( $5^{\mathrm{a}} \mathrm{ed}$.) [Multivariate analysis ( $\left.5^{\text {th }} \mathrm{ed}.\right)$ ]. Madrid, Spain: Prentice-Hall.

Institute of Alcohol Studies (2007). Binge drinking: Nature, prevalence and causes. London, England: Author. Retrieved from http://www.ias.org.uk/resources/factsheets/binge_drin king.pdf

Jackson, K. M. (2008). Heavy episodic drinking: Determining the predictive utility of five or more drinks. Psychology of Addictive Behaviors, 22, 68-77. http://dx.doi.org/10.1037/0893164X.22.1.68

Kuntsche, E., Rehm, J., \& Gmel, G. (2004). Characteristics of binge drinkers in Europe. Social Science \& Medicine, 59, 113-127. http://dx.doi.org/10.1016/j.socscimed.2003.10.009
Lange, J. E., \& Voas, R. B. (2001). Defining binge drinking quantities through resulting blood alcohol concentrations. Psychology of Addictive Behaviors, 15, 310-316. http://dx. doi.org/10.1037//0893-164X.15.4.310

Marczinski, C. A., Comb, S. W., \& Fillmore, M. T. (2007). Increased sensitivity to the disinhibiting effects of alcohol in binge drinkers. Psychology of Addictive Behaviors, 21, 346354. http://dx.doi.org/10.1037/0893-164X.21.3.346

Maurage, P., Pesenti, M., Philippot, P., Joassin, F., \& Campanella, S. (2009). Latent deleterious effects of binge drinking over a short period of time revealed only by electrophysiological measures. Journal of Psychiatry Neuroscience, 32, 111-118.

Miller J. W., Naimi T., Brewer R., \& Everett Jones, S. (2007). Binge drinking and associated health risk behaviors among high school students. Pediatrics, 119, 76-85. http://dx.doi.org/ 10.1542/peds.2006-1517

Ministerio de Sanidad y Consumo (2008). Prevención de los problemas derivados del alcohol. [Prevention of alcohol problems] Madrid, Spain: Ministerio de Sanidad y Consumo. Retrieved from http://www.msps.es/alcoholJovenes/docs/preven cionProblemasAlcohol.pdf

Navarrete, L. (2004). Juventud y drogodependencias: Cuatro estudios sociológicos comparados [Youth and drugs: four compared sociological studies]. Madrid, Spain: Colegio de Doctores y Licenciados en Ciencias Políticas y Sociología, Plan Nacional sobre Drogas. Retrieved from http://www.pnsd. msc.es/Categoria2/publica/pdf/JuventudDrogodependencias.pdf

Observatorio Español sobre Drogas (2007). Situación y tendencias de los problemas de drogas en España [Status and trends of drug problems in Spain]. Madrid, Spain: Plan Nacional sobre Drogas, Ministerio de Sanidad y Consumo. Retrieved from http://www.pnsd.msc.es/Categoria2/publica/pdf/oed-2007.pdf

O’Malley, P. M., Johnston, L. D., \& Bachman, J. G. (1998). Alcohol use among adolescents. Alcohol Health \& Research World, 22, 85-93.

Perkins, H. W., DeJong, W., \& Linkenbach, J. (2001). Estimated blood alcohol levels reached by "binge" and "nonbinge" drinkers: A survey of young adults in Montana. Psychology of Addictive Behaviors, 15, 317-320. http://dx.doi.org/10.1037// 0893-164X.15.4.317

Picón, E., Varela, J., \& Real, E. (2003). Clasificación y segmentación post hoc mediante el análisis de conglomerados [Post hoc classification and segmentation using cluster analysis]. In J. P. Lévy \& J. Varela (Eds.), Análisis multivariable para las ciencias sociales [Multivariate analysis for the social sciences] (pp. 417-450). Madrid, Spain: Pearson Educación.

Plaza, B., Pardo, F., Cortés, M. T., Samper, P., \& Martínez, A. (2006, March). Cómo trata la prensa valenciana el fenómeno del botellón: necesidad de superar una visión restrictiva. [How valencian press treats the botellon phenomenon: the need to overcome a restrictive vision]. Paper presented at the XXXIII Jornadas National Conference Socidrogalcohol, Cáceres, Spain.

Sánchez, L. (2007). Estudio sobre los hábitos de consumo de bebidas alcohólicas en espacios públicos "botellón" de los jóvenes castellanoleoneses [Study on the habits of drinking 
alcohol in public spaces "botellon" of young Castilian Leonese]. Valladolid, Spain: Junta de Castilla y León. Retrieved from http://www.vieiro.org/web/notic.php?ide $=7412 \&$ idc $=1$

Sánchez, M. J. (2001). El botellón [The botellon]. (Unpublished master's thesis). Universidad Complutense, Madrid, Spain.

Tapert, S. (2007, April). Consumo de alcohol en Adolescentes: efectos sobre el cerebro [Teen alcohol consumption: effects on the brain.]. Paper presented at the International Seminar on alcohol and brain damage in children. Madrid, Spain.

Turrisi, R. (1999). Cognitive and attitudinal factors in the analysis of alternatives to binge drinking. Journal of Applied Social Psychology, 29, 1512-1535. http://dx.doi.org/10.1111/j.15591816.1999.tb00150.x

Wagner, T. H., Harris, K. M., Federman, B., Dai, L., Luna, Y., \& Humphreys, K. (2007). Prevalence of substance use disorders among veterans and comparable nonveterans from the National Survey on Drug Use and Health. Psychological Services, 4, 149-157. http://dx.doi.org/10.1037/1541-1559.4.3.149
Wechsler H., \& Nelson, T. F. (2001). Binge drinking and the American college student: What's five drinks? Psychology of Addictive Behaviors, 15, 287-291. http://dx.doi.org/10.1037/ 0893-164X.15.4.287

Wechsler, H., Davenport, A., Dowdall, G. W., Moeykens, B. A., \& Castillo, S. (1994). Health and behavioral consequences of binge drinking in college. The Journal of the American Medical Association, 272, 1672-1677. http://dx.doi.org/10. 1001/jama.1994.03520210056032

White, A. (2007, April). Alcohol: Una amenaza para el desarrollo neuropsicológico de los adolescentes [Alcohol: A threat to the neuropsychological development of adolescents]. Paper presented at the International Seminar on alcohol and brain damage in children. Madrid, Spain.

Received March 1, 2010

Revision received January 14, 2011

Accepted April 10, 2011 